HORIZON 7 (1) 2018 : I. Research : P. Berghofer : 121-136

ФЕНОМЕНОЛОГИЧЕСКИЕ ИССЛЕДОВАНИЯ • STUDIES IN PHENOMENOLOGY • STUDIEN ZUR PHÄNOMENOLOGIE • ÉTUDES PHÉNOMÉNOLOGIQUES

https://doi.org/10.21638/2226-5260-2018-7-1-121-136

\title{
NEW WAYS TO TRANSCENDENTAL PHENOMENOLOGY: WHY EPISTEMOLOGY MUST BE A DESCRIPTIVE AND EIDETIC STUDY OF CONSCIOUSNESS
}

\section{PHILIPP BERGHOFER}

$\mathrm{PhD}$ in Philosophy, Academic Staff Member.

University of Graz, Faculty of Humanities.

8010 Graz, Austria.

E-mail: philipp.berghofer@uni-graz.at

Husserl has spilled much ink motivating the transcendental reduction that is supposed to pave the way for the ultimate, subjective science, i.e., transcendental phenomenology. However, Husserl's original ways to the transcendental reduction are problematic. One such issue concerns the (in)fallibility of apodictic evidence. If apodictic evidence must be infallible, the project of transcendental phenomenology seems to be unattainable. However, if apodictic evidence is fallible, the project of transcendental phenomenology is not as well-motivated as seemingly implied by Husserl's Cartesian way. In the present paper, I put forward new ways to transcendental phenomenology that are based on arguments in current analytic epistemology. I show that the new evil demon problem, Laurence BonJour's example of clairvoyance, and the phenomenon of blindsight can not only be used to make a case against reliabilism, but also to motivate the core ideas of transcendental phenomenology. The underlying conviction of this paper is that any argument or line of reasoning that, for epistemological reasons, motivates the study of consciousness in a non-empirical descriptive and eidetic fashion can be considered a way to transcendental phenomenology. The thesis of this paper is that one such way to transcendental phenomenology can be found by engaging in current epistemological debates. I exemplify this new way to the reduction by discussing concrete problems, putting particular emphasis on the new evil demon problem as it allows us to motivate a phenomenological version of epistemic internalism, according to which two experiences that are phenomenologically identical are also justificationally identical, which means that they justify the same beliefs to the same degree.

Key words: Transcendental phenomenology, epistemology, Husserl, transcendental reduction, phenomenological epistemology.

(C) PHILIPP BERGHOFER, 2018

HORIZON 7 (1) 2018 


\section{НОВЫЕ ПУТИ К ТРАНСЦЕНДЕНТАЛЬНОЙ ФЕНОМЕНОЛОГИИ: ПОЧЕМУ ЭПИСТЕМОЛОГИЯ ДОЛЖНА БЫТЬ ОПИСАТЕЛЬНЫМ И ЭЙДЕТИЧЕСКИМ ИССЛЕДОВАНИЕМ СОЗНАНИЯ}

\section{ФИЛИПП БЕРГХОФЕР}

Доктор философии, преподаватель.

Университет Граца, факультет гуманитарных наук.

8010 Грац, Австрия.

E-mail: philipp.berghofer@uni-graz.at

Гуссерлем было много написано о мотивации трансцендентальной редукции, призванной проложить путь к наивысшей субъективной науке, т. е. трансцендентальной феноменологии. Однако собственные пути Гуссерля к трансцендентальной редукции являются проблематичными. Одной из таких проблем является (не)погрешимость аподиктической очевидности. Если аподиктическая очевидность должна быть непогрешимой, то проект трансцендентальной феноменологии кажется неосуществимым. Но если аподиктическая очевидность может быть ошибочной, проект трансцендентальной феноменологии не столь хорошо мотивирован, как это, по-видимому, предполагает картезианский путь к редукции у Гуссерля. В данной статье мы предложим новые пути к трансцендентальной феноменологии, которые исходят из дебатов в современной аналитической эпистемологии. Я покажу, что новая проблема злого демона, пример с ясновидящим у Л.Бонжура и феномен слепозрения, не только могут быть использованы как аргументы против релиабилизма, но и для того, чтобы мотивировать ключевые идеи трансцендентальной феноменологии. Основополагающее убеждение автора этой статьи заключается в том, что любой аргумент или линия рассуждений, которые по эпистемологическим соображениям мотивируют исследование сознания посредством неэмпирического дескриптивного и эйдетического метода могут рассматриваться в качестве пути к трансцендентальной феноменологии. Тезис этой статьи заключается в том, что один из таких путей к трансцендентальной феноменологии может быть найден в рамках современных эпистемологических дебатов. Мы проиллюстрируем этот новый путь к редукции посредством обсуждения конкретных проблем, делая основной акцент на новой проблеме злого демона, так как последняя дает нам мотивацию для феноменологической версии эпистемического интернализма, в соответствии с которым два переживания, которые тождественны феноменологически, тождественны также по статусу обоснования, что означает, что они обосновывают одни и те же убеждения в одной и той же степени.

Ключевые слова: Трансцендентальная феноменология, эпистемология, Гуссерль, трансцендентальная редукция, феноменологическая эпистемология.

\section{INTRODUCTION}

The present paper aims to exemplify how engaging with current debates in analytic epistemology can help to motivate transcendental phenomenology. In the following, we see the premises and the main thesis of this paper:

(1) Husserl's transcendental reduction is epistemologically motivated and is intended to rebut the charge of psychologism that has been raised against the Logical 
Investigations (Husserl, 2002, 312; Husserl, 1984, 424 ff.; Melle's remarks in Husserl, 1984, XXXII).

(2) Husserl's project of transcendental phenomenology is a project of ultimate elucidation - it is intended to reveal the ultimate epistemological principles (Husserl, 1984, 165).

(3) Husserl's project of transcendental phenomenology should not be intended as a project striving for infallibility. Ultimate elucidation must not be confused with infallible justification. Ultimate elucidation means elucidating the ultimate epistemological principles. This does not require that all our justification is infallible. It does not even require that our justification for the ultimate principles is infallible!

(4) Husserl's transcendental phenomenology is subjective or idealist in the sense that he believes that only a descriptive, first-person perspective investigation of one's own consciousness can lead to the ultimate science, to phenomenology as a First Philosophy that aims at ultimate elucidation. In this sense, and only in this sense, Husserl's transcendental phenomenology can be called an egology (Husserl, 1973, 69).

(5) Husserl's transcendental phenomenology is eidetic in that he believes that one's descriptive investigations of one's own consciousness must be complemented by eidetic variations. What phenomenology is concerned with is not concrete phenomena but general, a priori structures of consciousness (Husserl, 2002, 312).

(6) Husserl's transcendental phenomenology is transcendental in that it investigates consciousness and the givenness of objects in its various modes "in suspension of all empirical positings" (Husserl, 1984, 424 ff.; Husserl, 2002, 152).

(7) Husserl's original ways to the transcendental reduction are problematic. While I agree with Drummond (1975) and Luft (2004) that the Cartesian way and the way through ontology are intended to complement each other, there still remain a number of problems, in particular the issue of the (in)fallibility of apodictic evidence. If apodictic evidence must be infallible, the project of transcendental phenomenology seems to be unattainable. If apodictic evidence can be fallible, the project of transcendental phenomenology is not as well-motivated as seemingly implied by the Cartesian way.

(8) As Husserl has pointed out, "there are various ways to phenomenology". (Husserl, 2000, 201) I take it that any argument or line of reasoning that, for epistemological reasons, motivates the study of consciousness in a non-empirical descriptive and eidetic fashion can be considered a way to transcendental phenomenology.

(9) One way to transcendental phenomenology in the sense specified in (8) can be found by discussing certain problems in current analytic epistemology. 
I take it that (1), (2), (4), (5), (6) are well in line with Husserl's ideas and statements and are rather uncontroversial (although Husserl scholars, who interpret Husserl's transcendental idealism as a metaphysical idealism may oppose the wording of (4)). (3) and (7) are phenomenological-systematic claims. There are passages in Husserl's oeuvre that suggest that he considers apodictic evidence to be infallible which implies that the Cartesian way is intended to lead to an infallible science or at least to an infallible starting point. However, there are also passages that suggest the fallibility of apodictic evidence (cf. Husserl, 1974, 164; Husserl, 1987, 248). More importantly, there is no systematic reason why phenomenologists should subscribe to the infallibility thesis. The present paper is supposed to show that there are ways to transcendental phenomenology that are not committed to the infallibility thesis.

(1) - (7) lead up to (8). According to (8), any argument or line of reasoning that, for epistemological reasons, motivates the study of consciousness in a non-empirical descriptive and eidetic fashion can be considered a way to transcendental phenomenology. (9) claims that one such way to transcendental phenomenology can be found by engaging in current epistemological debates. The present paper is supposed to exemplify this claim.

\section{STEPS TOWARDS TRANSCENDENTAL PHENOMENOLOGY}

An effective and thorough way to transcendental phenomenology would consist of the following three steps:

Step 1: Offering reasons why the individual sciences cannot provide ultimate elucidation on their own. Mathematical and natural-scientific methods work well for mathematics and the natural sciences but not for the task of ultimate elucidation. Ultimate elucidation is the task of philosophy. Any argument against empiricism, psychologism, and (epistemic) naturalism in general can be seen as taking step 1 towards transcendental phenomenology. We find such arguments, e.g., in the Prolegomena, the beginning of Ideas I (in particular paragraph 20), and in Philosophy as a Rigorous Science.

Step 2: Offering reasons why ultimate elucidation and epistemology must be subjective in the sense of a descriptive eidetic investigation of consciousness. The Cartesian way and the way through ontology can be seen as attempting to take step 2 towards transcendental phenomenology.

Step 3: Showing that a phenomenological epistemology is plausible and has advantages over rival epistemological theories. In step 3, the whole project of transcendental phenomenology gains support from its plausible consequences. 
In his published works Husserl was mainly concerned with step 1 and step 2. That the whole project of transcendental phenomenology can gain motivation by demonstrating how its results are superior to those of rival theories is too seldom made explicit. This is particularly true for current phenomenological research. Rarely, if ever, do phenomenologists specify their fundamental epistemological principles, confront them with contemporary rival theories, and illustrate the advantages of a phenomenological epistemology ${ }^{1}$.

One may object that it is in principle impossible to motivate a theory or project by its results. This is simply not true. Assume you are a confectioner and are convinced that using ingredient I will result in perfect ice cream. Of course, you can try to convince other people by providing scientific facts about the relationship between ingredient I and human taste receptors. Alternatively, you can also simply make the ice cream and let people taste it for themselves ${ }^{2}$. In what follows, I shall discuss three concrete examples popular in current epistemological debates and show that discussing these examples can make contributions to step 2 and step 3. This means that I will argue that these examples indicate that epistemology should be a descriptive and eidetic study of consciousness (step 2) and that phenomenological-epistemological principles provide a theoretical framework for understanding these examples that has advantages over rival theories such as reliabilism (step 3).

\section{NEW WAYS TO TRANSCENDENTAL PHENOMENOLOGY}

\subsection{THE NEW EVIL DEMON PROBLEM}

In the second half of the $20^{\text {th }}$ century, an externalist conception of epistemic justification emerged that still enjoys popularity and now goes by the label of reliabilism. Reliabilism comes in many forms, process reliabilism being the most common and most widely discussed form of reliabilism. The basic idea of process reliabilism can be expressed as follows:

Process reliabilism: A belief is justified if and only if the belief is formed by a reliable process.

1 Among the notable exceptions confronting phenomenology with analytic epistemology aiming at highlighting the fruitfulness of such confrontations are Hopp (2016), Pietersma (2000), Wiltsche (2015) and the controversies between Hopp and Rinofner-Kreidl (Rinofner-Kreidl, 2013; Hopp, 2013) and Hopp and Heffernan (Hopp, 2009; Heffernan, 2009).

2 In our context we may say that we motivate transcendental phenomenology by its intuitive consequences and explanatory power. 
A belief-forming process is reliable if it produces mostly true beliefs. The virtue of reliabilism is that it manages to implement a close connection between justification and truth. Many epistemologists have the intuition that truth is the ultimate aim not only of philosophy but of any science and that a plausible conception of justification, thus, must be able to account for the significance of reaching the truth (David, 2014). However, an externalist conception of justification such as reliabilism is anti-phenomenological. Not only because if reliabilism were true, there would be no motivation for a descriptive, eidetic investigation of consciousness, but also because it directly contradicts the basic theses of a phenomenological epistemology. By these basic theses I understand the claims that (i) experiences are the ultimate source of justification (cf. Husserl, 1976, 43), (ii) experiences that possess the phenomenal character of originary givenness are an immediate source of justification (Husserl, 1976, 51), and (iii) originary presentive experiences gain their justificatory force precisely from their character of originary givenness (Husserl, 1976, 43; Husserl, 1984, 347) . $^{3}$

Reliabilism is silent with respect to (i) and (ii) and incompatible with (iii). A reliabilist account of experiential justification could be introduced as follows:

Experience-Reliabilism: An experience is a source of immediate justification if and only if the experience is formed by a reliable process.

An experience-forming process is reliable if it produces mostly veridical experiences. If the reliabilist holds that only originary presentive intuitions are formed by reliable processes, the reliabilist is in agreement with (i) and (ii). However, reliabilism obviously violates the subjective and internalist spirit of phenomenology which is best seen in the incompatibility of reliabilism with (iii). Of course, we do not want to dismiss reliabilism simply for the reason that it is anti-phenomenological. One of the most popular arguments against reliabilism stems from the so-called new evil demon problem (NEDP). By discussing NEDP, I want to reveal not only the shortcomings of reliabilism but also to indicate how such an example leads us to transcendental phenomenology.

NEDP can be traced back to Lehrer and Cohen 1983 and is supposed to show that, contrary to what is entailed by reliabilism, reliability cannot be necessary for justification:

Imagine that, unknown to us, our cognitive processes, those involved in perception, memory and inference, are rendered unreliable by the actions of a powerful demon or malevolent scientist. It would follow on reliabilist views that under such conditions the beliefs generated by those processes would not be justified. This result is unacceptable. (Lehrer, Cohen, 1983, 192)

3 For more details on a phenomenological epistemology and, in particular, the claim that certain experiences gain their justificatory force by virtue of their distinctive phenomenal character (Berghofer, 2018a; Berghofer, 2018b). 
Clearly, the new evil demon problem is inspired by Descartes's "old" evil demon problem. The important difference is that while Descartes used the evil demon scenario to distinguish fallible from infallible beliefs, NEDP aims at revealing an essential feature of epistemic justification: reliability is not necessary for justification. If I live in the "good world" in which most of my perceptual experiences are veridical and my internal twin lives in the "bad world" in which an evil demon causes my internal twin to have experiences that are indistinguishable from mine but are systematically unreliable, then, if we both have an experience of a red book in front of us, we are both to the same degree justified in believing that there is a red book. In my case, there really is a red book. In the case of my internal twin, the book may be green or even be a hallucination. The point is that epistemologists have the strong intuition that, given that our experiences are phenomenologically indistinguishable, we are both justified to the same degree in believing that there is a red book, which implies that reliabilism is mistaken since reliability is not a necessary condition for justification.

NEDP has often been used to argue in favor of an internalist conception of justification called mentalism. We may introduce this idea as follows:

Mentalism: If M1 describes exhaustively the inner life of agent S1 and M2 the inner life of agent S2, then, if $M 1=M 2, S 1$ and S2 have the same degree of justification for their respective beliefs.

This implies that epistemic justification supervenes on the mental which is why mentalism is often introduced as follows: “The justificatory status of a person's doxastic attitudes strongly supervenes on the person's occurrent and dispositional mental states, events, and conditions" (Conee, Feldman, 2004, 56).

Thus, NEDP not only casts serious doubt on reliabilism, it also indicates that epistemology should first and foremost be concerned with the mental. Concerning the supervenience thesis, importantly, we find a similar claim in Husserl:

\footnotetext{
A statement is grounded in experience, more precisely in perception and memory. It carries, so to speak, empirical weight. The clearer and more distinct the fulfilling empirical consciousness of givenness is, the more weight it carries. Obviously, we are not in a realm of contingent psychological subjectivity here either. Perception justifies by its phenomenological content, by its essence. Every singular perception with the same essence would justify "the same" statement proper to it in a precisely similar way, no matter where and for whom. (Husserl, 2008, 343, translation modified)
}

With respect to epistemic justification, this is one of the most important passages in Husserl's oeuvre. Let us focus on the claim that "[p]erception justifies by its phenomenological content, by its essence. Every singular perception with the same essence would justify 'the same' statement proper to it in a precisely similar way, no matter where 
and for whom" (my emphasis). This expresses the view that phenomenologically indistinguishable experiences provide the same degree of justification for the same beliefs. This suggests the above-mentioned supervenience thesis: Epistemic justification supervenes on the agent's mental life. Two persons who differ justificatorily need also to differ mentally. Hence, Husserl subscribes to mentalism.

However, I believe that NEDP and Husserl's statement that "[e]very singular perception with the same essence would justify 'the same'statement proper to it in a precisely similar way, no matter where and for whom" tell us something even more fundamental about epistemic justification. Note that mentalism does neither specify which mental states are particularly epistemically significant nor what it is that makes certain experiences justifiers. It has been argued that mentalism, as it is introduced above, does not really qualify as an internalist position since conceptions that are traditionally viewed as externalist might be compatible with mentalism (Pritchard, 2011). Here the prime example is Williamson's famous formula $\mathrm{E}=\mathrm{K}$. Williamson contends "that one's total evidence is one's total knowledge" (Williamson, 2005, 468). Since Williamson also argues that knowledge is a mental state, his knowledge-first epistemology qualifies as a version of mentalism: One's evidence (i.e., justification) supervenes on one's knowledge and since knowledge is a mental state this means that justification supervenes on the mental.

On the other hand, consider disjunctivists who hold that (i) veridical perception is essentially distinct from illusion and hallucination even if these mental states are phenomenologically indistinguishable and (ii) only veridical perception is a source of justification, but not illusion or hallucination. Even such disjunctivists could subscribe to mentalism, but note that Williamson and disjunctivists have a different response to NEDP. Since the internal twin in the bad world does not have knowledge and veridical perceptions about the world, Williamson and disjunctivists must deny that the internal twins (one in the good and one in the bad world) have identical mental states. Also, Williamson is forced to deny that the non-veridical experiences of the person in the bad world can have justificatory force (at least they cannot justify beliefs about the world to the same degree as veridical perceptions).

In order to sidestep Williamson's view or disjunctivist accounts qualifying as a version of mentalism, mentalism is often defined as follows: One's justification supervenes on one's non-factive mental states. Since knowledge and veridical perception are factive, mentalism can, by this means, avoid the embarrassment of classifying seemingly externalist positions as a version of internalism. However, this solution seems ad hoc and mentalism still does not provide an answer to the question of why certain mental states have justificatory force. I believe that NEDP suggests a more specific answer: 
Phenomenological Internalism: If two experiences are exactly alike phenomenologically, then they are alike justificationally, e.g., they justify the same beliefs to the same degree 4 .

In this context Duncan Pritchard states:

"Finally, I take it that the thesis that underlies (NEG) [in our terminology: NEDP] is the following:

DISC. If the experiences had by $S$ and $S^{*}$ are indiscriminable then $S$ and $S^{*}$ will not differ in the degree of epistemic justification that they have for their beliefs"s (Pritchard, 2011, 238).

I believe that Phenomenological Internalism is not only the lesson we should learn from NEDP but that it also captures precisely Husserl's thoughts when he states that "[e]very singular perception with the same essence would justify 'the same' statement proper to it in a precisely similar way, no matter where and for whom". Let me illustrate the plausibility of Phenomenological Internalism by Husserl's method of eidetic variation. We begin with the concrete example of having a perceptual experience of a black laptop. Assume your experience has the character of originary givenness with respect to "there is a laptop", "this laptop is black", and "this laptop has a screen and a keyboard". All these aspects are originally given to you, which basically means that you seem to be visually aware of them. And let us also assume that your experience is veridical, which means that you really are visually aware of a black laptop. How could you vary this scenario such that your perceptual experience loses its justificatory force? Say, we only change the external conditions such that the experience's phenomenal character remains identical but the experience is a hallucination caused by whatever reason (evil demon, mad scientist, the Matrix, brain malfunction, etc.). Intuitively, just like in NEDP, we would say that the experience's justificatory force is not affected. Now assume that most of your perceptual experiences are reliable but, for whatever reason, whenever you sit in front of your desk and fold your hands, you have a perfect hallucination of a black laptop. Assume also, you know of this fact (that whenever you sit in front of your desk and fold your hands, you have a perceptual experience of a lack laptop that is a hallucination). In this case, it seems plausible to assume that you are not justified in believing that there is a black laptop. But here we need to distinguish between immediate and inferential justification. In this scenario,

4 This formulation is parallel to Conee and Feldman's definition of mentalism: "If any two possible individuals are exactly alike mentally, then they are alike justificationally, e.g., the same beliefs are justified for them to the same extent" (Conee, Feldman, 2004, 56).

5 It should be mentioned that Pritchard does not subscribe to DISC or Phenomenological Internalism. 
the reason why you are not justified in believing that there is a black laptop is that you know that this perceptual experience is a hallucination. The most plausible story we can tell about this scenario is that the hallucination does provide immediate justification for believing that there is a black laptop but this justification is defeated by your background knowledge (namely that this experience is a hallucination). Thus, even in this scenario, the perceptual experience is a source of immediate justification. These scenarios are the starting-points that are intended to help you to apodictically intuit that you cannot vary this case in such a manner that the perceptual character of the experience remains identical while the justificatory force of the experience diminishes. On the other hand, when you vary the phenomenal character, this can easily affect what and to what degree the experience justifies. Assume in our case that your perceptual experience does not seem to make you aware of a black laptop but of a green book. In this scenario, the experience does not have justificatory force for believing that there is a black laptop but that there is a green book. All this reinforces Phenomenological Internalism.

Note that accepting Phenomenological Internalism can be viewed as a way to transcendental phenomenology. We have clarified above that any argument or line of reasoning that, for epistemological reasons, motivates the study of consciousness in a non-empirical descriptive and eidetic fashion can be considered a way to transcendental phenomenology. Mentalism and Phenomenological Internalism not only suggest that epistemology must be a study of consciousness (since justification supervenes on the mental), but also that consciousness should be investigated in a non-empirical descriptive way (because an experience's justificatory force supervenes on its phenomenal character). Phenomenological Internalism as such was additionally motivated by eidetic variations. The theses that justification supervenes on the mental and that an experience's justificatory force supervenes on its phenomenal character are intended to be a priori epistemological truths.

\subsection{NORMAN THE CLAIRVOYANT}

While NEDP is often considered the most powerful argument against the reliabilist's claim that reliability is necessary for justification, BonJour's famous case of clairvoyance is intended to reveal that reliability also is not sufficient for justification. Let us take a look at BonJour's original example:

Norman, under certain conditions that usually obtain, is a completely reliable clairvoyant with respect to certain kinds of subject matter. He possesses no evidence or reasons of any kind for or against the general possibility of such a cognitive power, or for or 
against the thesis that he possesses it. One day Norman comes to believe that the President is in New York City, though he has no evidence either for or against this belief. In fact the belief is true and results from his clairvoyant power, under circumstances in which it is completely reliable. (BonJour, 1980, 62)

In this case, the belief that the President is in New York City is formed by a reliable process, but, intuitively, we would not say that this belief is justified. Again, we need to distinguish between immediate and inferential justification. If Norman knows that he has this clairvoyance power and that most or even all of his clairvoyant beliefs are true, then it might be plausible to assume that he is justified in believing that the President is in New York City. But such a clairvoyant seeming as such is not a source of immediate justification and since in this example BonJour specifies that Norman has no reason for believing that he is a reliable clairvoyant, he is not justified in believing that the President is in New York.

Let us, again, discuss various cases in order to gain a better understanding of the nature of justification.

Case 1: Norman possesses a mystical clairvoyant sphere. Whenever he touches the sphere, a true belief is caused. Norman touches the sphere which causes him to believe that the President is in New York City.

Case 2: Norman possesses a mystical clairvoyant sphere. Whenever he touches the sphere, a true event that takes place right now is displayed within the sphere such that the sphere can be used like a television for real events. Norman touches the sphere which causes the sphere to display the President giving a speech in New York.

Case 3: Norman possesses a mystical clairvoyant sphere. Whenever he touches the sphere, he sees the world through another person's eyes. Norman touches the sphere which causes him to see the world through the eyes of a person who is in New York watching the President giving a speech. Norman sees the President exactly as he would if he were there in person, but he cannot actively move his head or eyes to change the perspective.

Case 4: Norman possesses a mystical clairvoyant sphere. Whenever he touches the sphere, he is immediately transported to some other place on earth. Norman touches the sphere which causes him to appear in New York seeing the President giving a speech.

Case 1 is very similar to BonJour's original example, the only difference being that the clairvoyant belief is caused by touching the mystical sphere. Intuitively, such a belief cannot be immediately justified, whether or not it is formed by a reliable process. Such a belief can only be justified by background knowledge, which shows that 
the mere reliability of a belief-forming process cannot be sufficient for justification. Although this may suffice to reveal the shortcomings of reliabilism, in order to get a better understanding of the nature of justification, it is also instructive to consider the other cases. In case 2, Norman is justified in believing that the sphere displays the President giving a speech in New York. Why? Because he can see it. His perceptual experiences have an originary presentive character concerning the sphere displaying the President giving a speech. Norman is not immediately justified in believing that the President is in New York giving a speech. For this belief background justification about the reliability of the sphere is required. In case 3, Norman has a perceptual experience of the President giving a speech. This perceptual experience has immediate justificatory force concerning the belief that the President is giving a speech. The special circumstances, however, provide good reasons for (falsely) assuming that this experience is a mere hallucination. Thus, the belief that the President is giving a speech is defeated by these reasons and can only be reinforced by background knowledge about the reliability of this process. In case 4 , the situation is similar. Seeing the President justifies Norman in believing that the President is there giving a speech, but this belief may be defeated by his knowledge that it is not normal to be teleported to other places. It may take Norman a while to realize that this is not a bad dream.

The discussion of these examples is supposed to show not only that an external factor such as reliability cannot disclose the nature of justification but also that experiences are a source of immediate justification and that this is so due to their distinctive phenomenal character of originary givenness.

The following subsection will shed more light on the significance of an experience's phenomenal character and motivate the phenomenologist's core idea that establishing epistemological principles must be preceded by phenomenological (i.e., descriptive, first-person) analyses.

\subsection{THE PHENOMENON OF BLINDSIGHT}

The more precise your phenomenological analysis of experiences, the more accurate your conception of experiential justification can become. This shall be illustrated by discussing a philosophically significant real-world example, the phenomenon of blindsight. Chris Tucker describes the phenomenon as follows:

Subjects who have a damaged visual cortex often emphatically report that they cannot see anything within a certain region of their visual field. Nonetheless, such subjects often show remarkable sensitivity (though less than properly functioning humans) to such 
things as motion, the orientation of objects, and the wavelength of light within their reported "blind spot". These subjects are typically surprised to discover their success, thinking that they were making random guesses. (Tucker, 2010, 530)

Consider the following example that is simplified but motivated by experimental-psychological investigations: A blindsighted person S looks at a piece of paper with a circle in S's region of normal sight (region R1) and a triangle within S's blind spot (region R2). Based on her perceptual experience, $S$ judges that there is a circle in $\mathrm{R} 1$ and a triangle in R2. Are both judgments equally justified? Even if we stipulate that the perceptual experience makes it seem to $S$ that there is a circle in $R 1$ and makes it seem to her that there is a triangle at $\mathrm{R} 2$, and that both seemings are formed by equally reliable processes, there still is an important phenomenological difference.

Clearly, S's perceptual experience has an originally presentive character with respect to the circle. $S$ seems to be visually aware of the circle; the circle is presented to her within experience. This, however, is not true for the triangle. The triangle is only co-given to $S$ in the sense that $S$ anticipates there to be a triangle. She has the anticipation that by moving her head, she will become aware of a triangle. The triangle is in the horizon of her perceptual experience but it is not presented to her. This phenomenological difference fits perfectly with the epistemological difference. S's perceptual experience provides her with immediate justification for believing that there is a circle in R1. She sees that there is a circle, thus she is immediately justified in believing that there is one. Intuitively, however, S's perceptual experience does not provide her with immediate justification that there is a triangle in R2. Of course, if $S$ knows that her blindsight faculties are reliable in the sense that in the past most of her blindsight seemings have turned out to be veridical, then $\mathrm{S}$ may be inferentially justified in believing that there is a triangle. Based on her blindsight seeming and based on her knowledge that her blindsight seemings are reliable, she can justifiably believe that there is a triangle. But such justification cannot be immediate. A plausible conception of perceptual justification should be able to avoid the consequence that blindsight seemings can be an immediate source of justification (Ghijsen, 2016, 17-19; Smithies, 2014, 103 ff.).

Like BonJour's example of clairvoyance, the phenomenon of blindsight is often used to argue that reliability is not sufficient for justification (Ghijsen, 2016; Smithies, 2014). What is often overlooked is that such examples do not only indicate the failure of reliabilism but also motivate the close connection between epistemology and philosophy of mind and the significance of purely phenomenological analyses in particular. What these examples indicate is that a descriptive, first-person analysis of experiences must be at the very beginning of all epistemology. Epistemology must 
be an analysis of experiences and this analysis cannot be proceeded "from above" by linking the justificatory force of experiences to external factors such as reliability. Types of justification (immediate vs inferential) and degrees of justification are linked to modes of givenness. What is given originally, and only what is given originally, can be immediately justified (Husserl, 1976, 326). Also, the clearer and more distinct the experience is, the more justification it provides (Husserl, 1984, 347).

The three examples discussed in this section (NEDP, clairvoyance, and the phenomenon of blindsight) indicate that a non-empirical descriptive study of consciousness must be the foundation for all epistemological investigations. The results we have gained (such as that justification supervenes on the mental and that an experience's justificatory force supervenes on its phenomenal character) are not intended to be empirical generalizations but a priori truths gained by eidetic variations. Accordingly, we can say that our discussions of these examples can be considered ways to transcendental phenomenology.

Phenomenologists may object that these new ways to transcendental phenomenology fail to establish phenomenology as an infallible science. But this requirement cannot be met anyway - not by the way through ontology, nor even by the Cartesian way. As discussed above, ultimate elucidation must not be confused with infallibility. Phenomenology is supposed to be the ultimate science in the sense of ultimately elucidating all sources of justification. It is Husserl's conviction that such ultimate elucidation can only be reached by a non-empirical, descriptive science of consciousness that aims at eidetic intuitions of general epistemological principles. In this section, we have seen that discussing examples that are currently popular counter-examples to reliabilism can play the role of leading to such a science, which is why we consider this to be a way to transcendental phenomenology.

Those contemporary epistemologists who may wish to be labeled analytic philosophers might object that discussing such examples and using them against reliabilism does not make them transcendental phenomenologists. I agree. What I have argued is that the discussion of these examples should make them subscribe to the fundamental thesis of transcendental phenomenology: No epistemology without phenomenology. Phenomenological descriptions are essential to epistemological investigations in the sense that the nature of justification can only be revealed by a non-empirical descriptive first-person analysis of experiences. Experiences justify by virtue of their distinctive phenomenal character and the more we learn about this character, the better for our epistemological investigations. By discussing NEDP, we have seen that justification supervenes on the mental and that if two experiences are exactly alike phenomenologically, then they are alike justificationally, e.g., they justify 
the same beliefs to the same degree. By discussing cases of clairvoyance and the phenomenon of blindsight, we have seen the close connection between epistemology and philosophy of mind and how plausible epistemological theories need to be preceded by phenomenological analyses. Thus, discussing such examples should motivate transcendental phenomenology, properly understood.

\section{REFERENCES}

Berghofer, P. (2018a). Husserl's Conception of Experiential Justification: What It Is and Why It Matters. Husserl Studies, 1-26. doi: 10.1007/s10743-018-9225-8

Berghofer, P. (2018b). Towards a Phenomenological Conception of Experiential Justification. Synthese, 1-29. doi: 10.1007/s11229-018-1744-5

BonJour, L. (1980). Externalist Theories of Empirical Knowledge. Midwest Studies in Philosophy, 5 (1), 53-73.

Conee, E., \& Feldman, R. (2004). Evidentialism. Oxford: Oxford University Press.

David, M. (2014). Truth as the Primary Epistemic Goal: A Working Hypothesis. In M. Steup, J. Turri, \& E. Sosa (Eds.), Contemporary Debates in Epistemology (363-377). Malden, MA: Wiley-Blackwell.

Drummond, J.(1975). Husserl on the Ways to the Performance of the Reduction. Man and World, 8 (1), 47-69.

Ghijsen, H. (2016). The Puzzle of Perceptual Justification. Switzerland: Springer.

Heffernan, G. (2009). On Husserl's Remark That „[s]elbst eine sich als apodiktisch ausgebende Evidenz kann sich als Täuschung enthüllen ..." (XVII 164:32-33): Does the Phenomenological Method Yield Any Epistemic Infallibility? Husserl Studies, 25, 15-43.

Hopp, W. (2009). Phenomenology and Fallibility. Husserl Studies, 25 (1), 1-14.

Hopp, W. (2013). Replies. Husserl Studies, 29 (1), 65-77.

Hopp, W. (2016). Phenomenal Conservatism and the Principle of All Principles. In D.Dahlstrom, A. Elpidorou, \& W. Hopp (Eds.), Philosophy of Mind and Phenomenology (180-202). New York: Routledge.

Husserl, E. (1973). Cartesianische Mediatationen und Pariser Vorträge (Hua I). The Hague: Nijhoff.

Husserl, E. (1974). Formale und transzendentale Logik (Hua XVII). The Hague: Nijhoff.

Husserl, E. (1976). Ideen zu einer reinen Phänomenologie und phänomenologischen Philosophie, Erstes Buch, Allgemeine Einführung in die reine Phänomenologie (Hua III-1). The Hague: Nijhoff.

Husserl, E.(1984). Einleitung in die Logik und Erkenntnistheorie. Vorlesungen 1906/07 (Hua XXIV). Dordrecht: Nijhoff

Husserl, E. (1987). Aufsätze und Vorträge (Hua XXV). Dordrecht: Nijhoff.

Husserl, E. (2000). Londoner Vorträge. Husserl Studies, 16, 183-254.

Husserl, E. (2002). Logische Untersuchungen. Ergänzungsband. Erster Teil. Entwürfe zur Umarbeitung der VI. Untersuchung und zur Vorrede für die Neuauflage der Logischen Untersuchungen (Sommer 1913) (Hua XX-1). Dordrecht: Kluwer.

Husserl, E. (2008). Introduction to Logic and Theory of Knowledge: Lectures 1906/07. Dordrecht: Springer.

Lehrer, K., \& Cohen, S. (1983). Justification, Truth, and Coherence. Synthese, 55 (2), 191-207.

Luft, S. (2004). Husserl's Phenomenological Reduction Revisited: An Attempt of a Renewed Account. Anuario Filosofico, 37 (1), 65-104.

HORIZON 7 (1) 2018 
Pietersma, H. (2000). Phenomenological Epistemology. Oxford: Oxford University Press.

Pritchard, D. (2011). Evidentialism, Internalism, Disjunctivism. In T. Dougherty (Ed.), Evidentialism and its Discontents (235-253). Oxford: Oxford University Press.

Rinofner-Kreidl, S. (2013). Mental Contents, Transparency, Realism: News from the Phenomenological Camp. Husserl Studies, 29 (1), 33-50.

Smithies, D. (2014). The Phenomenal Basis of Epistemic Justification. In M. Sprevak \& J. Kallestrup (Eds.), New Waves in Philosophy of Mind (98-124). New York: Palgrave Macmillan.

Tucker, C. (2010). Why Open-Minded People Should Endorse Dogmatism. Philosophical Perspectives, $24,529-545$.

Williamson, T.(2005). Replies to Commentators. Philosophy and Phenomenological Research, 70(2), 468-491.

Wiltsche, H. (2015). Intuitions, Seemings, and Phenomenology. Teorema, 34 (3), 57-77. 